\title{
Sensory, Physical and Nutritional Qualities of Cookies Prepared from Pearl Millet (Pennisetum Typhoideum)
}

\section{Florence Suma $\mathbf{P}^{1^{*}}$, Asna Urooj ${ }^{1}$, Asha $\mathbf{M R}^{2}$ and Jyotsna Rajiv}

${ }^{1}$ Department of Studies in Food Science and Nutrition, University of Mysore, Mysore, India

${ }^{2}$ Sensory Science, Central Food and Technology Research Institute, Mysore, India

${ }^{3}$ Flour Milling, Baking and Confectionary Technology, Central Food and Technology Research Institute, Mysore, India

\begin{abstract}
Refined wheat flour, a key ingredient in cookie is mainly composed of starch which is devoid of nutrients particularly minerals. This study determines the possibility of using two different pearl millet varieties K \& MRB ( $K$ and Maharashtra Rabi Bajra respectively) as a replacement for refined wheat flour in cookie preparation. Cookies were evaluated for proximate composition, textural and sensory characteristics. Proximate composition revealed that pearl millet cookies had higher protein, ash and mineral (iron, calcium \& phosphorus) content compared to control. Physical characteristics of cookies showed that the diameter of control, $\mathrm{K}$ and MRB cookies did not vary markedly. Quantitative Descriptive Analysis (QDA) method adopted to assess the sensory quality of the cookies revealed that cookies with pearl millet had better sensory profile compared to control. They had a combination of desirable and lasting vanilla-like aroma coupled with typical baked millet aroma. In addition, crisp and crumby texture perceived in these cookies further enhanced their sensory appeal making them highly palatable. This study indicates the prospects for utilization of pearl millet flour in preparing cookies with enhanced nutritional quality and sensory attributes.
\end{abstract}

Keywords: Pearl millet; Cookies; Nutritional quality; Sensory characteristics; Physical properties

\section{Introduction}

Baked products such as cookies are very popular among all age groups, especially with children. Cookies hold a significant place in the baking industry due to variety in taste, texture and aroma. They are low moisture foods with longer shelf life, generally prepared out of refined wheat flour, fat and sugar. Cookies are high fat - food products and obtain texture and flavour characteristics from the shortening used. Refined wheat flour is a key ingredient for preparing cookies due to its gluten content. However, refined wheat flour is a product of refining that contains higher proportion of starch, low dietary fibre and minerals and the resultant cookies are characterised with low proteins, fat and mineral content $[1,2]$. Therefore to improve its nutritive value, there is a need for replacing refined wheat flour with flour of better nutritive quality.

Pearl millet (Pennisetum typhoideum) is an important coarse cereal crop in western India (Gujarat, Rajasthan and Haryana). In 2011, 46\% of pearl millet produced was used for food, $37.5 \%$ for cattle feed, $7.7 \%$ for poultry feed, $8.8 \%$ for alcohol industry and as low as $0.4 \%$ for seed purpose [3]. It has potential for future human use due to its tolerance to difficult growing conditions such as drought, low soil fertility and high temperature and can be grown in areas where other cereal crops, such as maize (Zea mays) or wheat (Triticum aestivum), would not survive. Pearl millet contains substantial amount of minerals such as iron, calcium, zinc and high level of fat, it is nutritionally comparable and even superior to major cereals due to the energy and protein value [4-6]. Owing to lack of institutional support for millet crops in contrast to the institutional promotion of wheat, rice and maize continue to shrink the millet-growing region. While, pearl millet is nutritious, it is underutilized in developed countries due to non-availability in convenient/ ready to eat form $[7,8]$. Replacing of wheat flour with whole pearl millet flour has been researched previously. Cookies produced from $100 \%$ pearl millet were described as tough, hard, gritty, and mealy in texture and taste. They lacked spread and top surface cracks, which is a desirable attribute of cookies [9]. Presence of high concentration of pigments in the pericarp and endosperm regions of pearl millet resulted in undesirable gray color to its products. Further, improvement was achieved by depigmentation of pearl millet which was effective in improving the sensory attributes, in vitro protein digestibility, invitro starch digestibility, and soluble dietary fiber of pearl millet biscuits but also significantly decreased protein, starch and insoluble dietary fiber [1]. Pigments in pearl millet as a result of bran was successfully reduced by the process of semi refining that resulted in flour of some nutritional desirable qualities of both whole and refined flour. Semi refining of pearl millet reduced phytate and improved bioaccessibility of minerals like iron and calcium [10]. With this background, an attempt was made to formulate cookies by replacing refined wheat flour with semi refined pearl millet flour for two varieties namely K \& MRB.

\section{Materials and Methods}

\section{Ingredients}

Two Pearl millet cultivars namely $\mathrm{K}$ and MRB were procured for the study. Pearl millet grains were roasted in a pan at $200^{\circ} \mathrm{C}$ and ground into whole flour. The whole flour was sieved through a 44 mesh sieve (British Standard Sieve, microns - 355) to obtain Semi Refined Flour (SRF). Refined wheat flour was procured from local market. Other ingredients like shortening (Marvo brand, Hindustan Lever Ltd, Mumbai, India), Vanilla essence (Bush Boake Allen Ltd, Chennai, India), Skimmed milk powder (Everyday, Nestle, Gurgaon, Haryana) and sugar procured from local market were used in the study.

\section{Cookies formulation}

The formulation used for pearl millet cookies is presented in Table

*Corresonding author: Florence Suma P, Department of Studies in Food Science and Nutrition, University of Mysore, Mysore - 570006, Karnataka, India, Tel: 9740330523; Fax: 821-2419632; E-mail: florencesuma71@gmail.com

Received August 13, 2014; Accepted October 07, 2014; Published October 14 2014

Citation: Florence Suma P, Urooj A, Asha MR, Rajiv J (2014) Sensory, Physical and Nutritional Qualities of Cookies Prepared from Pearl Millet (Pennisetum Typhoideum) J Food Process Technol 5: 377. doi:10.4172/2157-7110.1000377

Copyright: (c) 2014 Florence Suma P, et al. This is an open-access article distributed under the terms of the Creative Commons Attribution License, which permits unrestricted use, distribution, and reproduction in any medium, provided the original author and source are credited. 
1. Cookies were prepared using semi refined pearl millet flour (SRFPM) and refined wheat flour (control) (Figure 1). A planetary mixer (Technoseat, model No. PM - 30, Cap - 300 ltr, New Delhi) was used to mix sugar, fat and vanilla powder at high speed (170 rpm, $15 \mathrm{~min})$. Subsequently, pearl millet flour was added and mixed at low speed (55 $\mathrm{rpm}, 20 \mathrm{~min}$ ). The cookies were sheeted to $10 \mathrm{~mm}$ thickness and cut into circular shape and baked for $20 \mathrm{~min}$ at $200^{\circ} \mathrm{C}$ in an electrically heated oven on a steel baking tray with butter paper. Cookie prepared using $100 \%$ refined wheat flour was used as control.

\section{Determination of proximate composition and mineral content}

Moisture was determined by moisture analyzer (Mettler Toledo IR moisture analyser, model no. MJ33, Max. Cap - 35 g / 0.01\%, Switzerland). Standard methods of AOAC [11] were used to determine fat by Soxhlet extraction, ash by combustion and protein content (Nx6.25) by micro Kjeldahl method. Mineral analysis was carried out on cookies digested with hydrochloric acid. Total calcium was analysed by Raghuramulu et al. method [12]. Phosphorus was analysed colorimetrically using Taussky \& Shorr method [13]. Total iron was analysed by colorimetric method using $\alpha$ a bipyridyyl method [11]

\section{Physical characteristics of cookies}

Physical parameters of pearl millet and control cookies such as weight, diameter $(\mathrm{D})$, thickness $(\mathrm{T})$ and spread ratio $(\mathrm{D} / \mathrm{T})$ were analysed. The spread factor was determined using the formula: (Spread factor of control/ Spread factor of experimental) $\times 100$.

\section{Sensory analysis}

Profiling of cookies was carried out in order to comparatively assess the sensory quality of control cookies prepared using refined wheat flour and experimental cookies prepared with pearl millet flour. Sensory evaluation was conducted under fluorescent light, with the booth area maintained at temperature $22 \pm 2{ }^{\circ} \mathrm{C}$ and $\mathrm{RH} 50 \pm 5 \%$. A suitable score card was designed using "Free-Choice Profiling" method. The attributes selected were grouped under modalities such as colour, texture, aroma taste etc. A descriptive method (QDA) was adopted to assess the quality of the cookies (Figure 2). Trained Panellists (10) were asked to mark on a scale of $0-15 \mathrm{~cm}$ to indicate the intensity of each attribute listed on the score card. The scale was anchored as 'low' and 'high' at $1.25 \mathrm{~cm}$ on either end, representing 'Recognition Threshold' and 'Saturation Threshold' respectively. Recognition threshold refers to the minimum concentration of a sensory stimulus that permits recognition/identification of the sensation perceived. That is, the lowest quantity of stimulus or least signal strength that needs to be present for the sensory receptors to identify or name the sensory stimulus. Saturation threshold refers to the concentration of sensory stimulus beyond which no further increase in its intensity is perceived, even when the concentration is increased physically. In other words, saturation threshold is the level of sensory perception beyond which further increase in intensity of stimulus is not perceived. Samples were presented one at a time in porcelain plates coded with 3-digit random numbers, to the panellists. Along with the samples, warm water and puffed rice were served as palate cleansers.

\section{Statistical analysis}

The data were subjected to analysis of variance (ANOVA) test and the differences between the means were compared for their significance $(\mathrm{p}<0.05)$ using SPSS (Statistical product and service solution) software v.17 (IBM corporation). The scores given for all the sensory attributes such as colour, texture, aroma, taste, etc., for each sample were tabulated. The mean value was calculated for each attribute of a sample, representing the panel's judgment about the sensory quality of the product. These were depicted graphically as sensory profiles.

\section{Results and Discussion}

Two pearl millet varieties namely $\mathrm{K}$ and MRB were selected for the study. $\mathrm{K}$ is a native variety, traditionally grown by farmers in India (Karnataka, Tamilnadu and Maharashtra). Its seeds are small and elongated with persisting glumes/husk. This variety is not improved by the modern plant breeding system but considered nutritionally very superior by the local people and is used as food crop to make roti, dumpling and chapathi (Figure 3 ). MRB is a commercially grown hybrid developed by the modern improved plant breeding technique by a commercial seed company. It is basically a winter crop and its seeds are grey/slate coloured, bold and round shaped without a persisting glumes/husk [14] (Figure 3).

The proximate composition of semi refined flour from pearl millet (SRFPM) and refined wheat flour used for cookie preparation are shown in Table 1. Protein, fat, iron and calcium content were found to be lower in K compared to MRB. However these values were higher in comparison with refined wheat flour.

Data in Table 3 represents proximate composition of cookies prepared from refined wheat flour (control) and two different varieties of pearl millet - K \& MRB respectively. Pearl millet cookies were characterised with a lower moisture content of $0.58 \% \& 0.34 \%$ for $\mathrm{K} \& \mathrm{MRB}$ respectively compared to that of control cookies (2.57\%). The reported moisture content for pearl millet cookies was higher and ranged from $2.57-2.67 \%$ [1]. Low moisture content may be attributed to the roasting of pearl millet prior to making of cookies. Cookies are low moisture baked products [15] and high moisture could results in a soggy and soft texture that leads to lower consumer acceptability. The fat content of the cookies ranged from $16.95 \%-19.71 \%$, with the lowest found in the control cookies, though these values did not differ significantly. Pearl millet is well identified for its high fat content [16] and also the high fat content could be due to addition of visible fat in the cookie recipe (Table 2). However, these results were lower that those reported [1]. The protein content of the cookies ranged from $6.8-8.63 \%$, with the highest seen in pearl millet cookies. Cookies made with refined wheat flour (control) contained $6.8 \%$ protein which increased to $8.63 \%$ and $8.5 \%$ when refined wheat flour was replaced with K \& MRB flour respectively. Similarly replacing refined wheat flour with SRF of K \& MRB increased ash content from $0.38 \%$ to $0.93 \%$

\begin{tabular}{|l|c|c|c|}
\hline \multirow{2}{*}{ Composition } & $\begin{array}{c}\text { Refined Wheat } \\
\text { Flour }\end{array}$ & \multicolumn{2}{|c|}{ SRFPM } \\
\cline { 3 - 4 } & $9.90^{\mathrm{a}} \pm 0.29^{\mathrm{a}}$ & $10.8^{\mathrm{b}} \pm 0.3$ & $9.5^{\mathrm{a}} \pm 0.8$ \\
\hline Moisture (g) & $7.87^{\mathrm{a}} \pm 0.29^{\mathrm{a}}$ & $8.5^{\mathrm{b}} \pm 0.7$ & $10.1^{\mathrm{c}} \pm 0.4$ \\
\hline Proteins (g) & $0.65^{\mathrm{a}} \pm 0.04^{\mathrm{a}}$ & $4.4^{\mathrm{b}} \pm 0.4$ & $5.0^{\mathrm{c}} \pm 0.1$ \\
\hline Fat (g) & $0.48^{\mathrm{a}} \pm 0.02^{\mathrm{a}}$ & $1.3^{\mathrm{b}} \pm 0.1$ & $1.3^{\mathrm{b}} \pm 0.2$ \\
\hline Ash (g) & 74 & 75 & 75 \\
\hline Carbohydrate ${ }^{*}$ & 348 & 374 & 382 \\
\hline Energy (K Cal) & $2.7^{\mathrm{a}} \pm 0.5$ & $4.06^{\mathrm{b}} \pm 0.5$ & $5.83^{\mathrm{c}} \pm 0.5$ \\
\hline Iron (mg) & $23^{\mathrm{a}} \pm 2.0$ & $45.6^{\mathrm{b}} \pm 2.3$ & $48.6^{\mathrm{c}} \pm 6.0$ \\
\hline Calcium (mg) & $121^{\mathrm{a}} \pm 10.0$ & $310.5^{\mathrm{c}} \pm 6.9$ & $270.0^{\mathrm{b}} \pm 20.9$ \\
\hline Phosphorus (mg) & & & \\
\hline
\end{tabular}

${ }^{*}$ Calculated by difference

K-Kalukombu

MRB - Maharashtra Rabi Bajra

NA - Not available

SRFPM - Semi Refined Flour from Pearl Millet

Table 1: Proximate Composition of Refined Wheat Flour and Semi Refined Pearl Millet Flour (per 100g) 


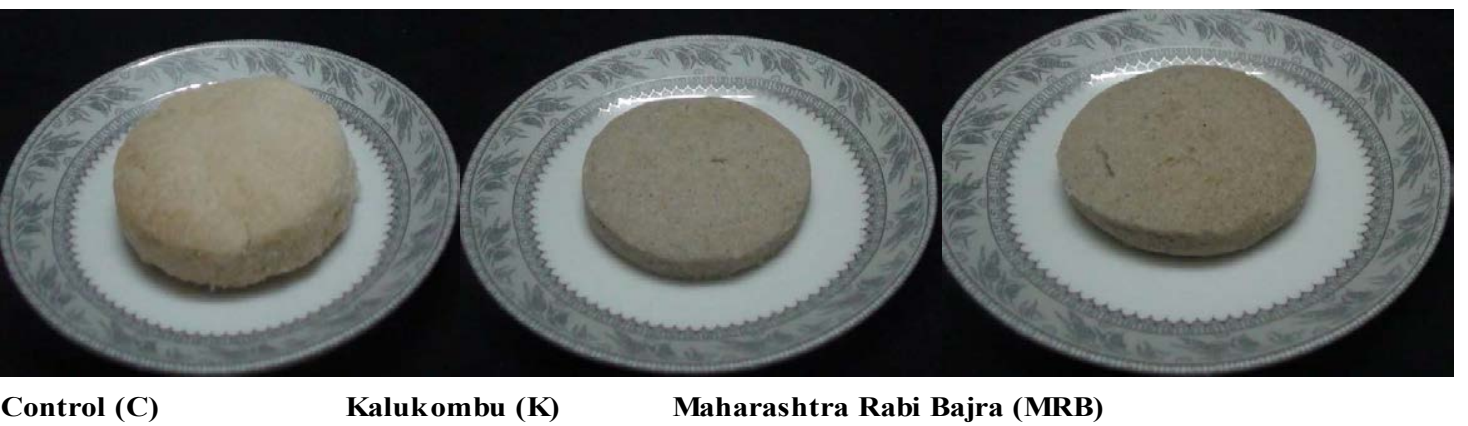

Figure 1: Cookies Prepared out of $100 \%$ Refined Wheat Flour (Control) and Pearl Millet (K \& MRB)

(K) and $0.77 \%(\mathrm{MRB})$ with a highest increase seen in $\mathrm{K}$ cookies, with the highest increase seen in $\mathrm{K}$ variety.

The iron and phosphorus levels of $\mathrm{K} \& \mathrm{MRB}$ were similar except for calcium content which was significantly $(\mathrm{p}<0.05)$ higher in MRB (Table 4). Replacement of refined wheat flour with SRFPM in cookies significantly $(\mathrm{p}<0.05)$ increased the levels of iron, calcium and phosphorus from $2.48 \%, 18.26 \%$ and $86.7 \%$ to $6.39 \%, 25.79 \%$ \& $208.1 \%$ for K while $6.71 \%, 29.36 \%$ and $190 \%$ for MRB.

Gluten influences the cookie diameter and spread onset time which is again dependent on the amount water available to the non - gluten constituents [17]. Although gluten free, pearl millet cookies which had a diameter of about $87 \mathrm{~mm}$ was comparable with the diameter of control cookie $-88 \mathrm{~mm}$ (Table 5) and also matched with the sugar snap cookies which were prepared with added gluten at various levels (74-97 mm) [17]. Thickness of pearl millet cookies (K \& MRB) was similar to the control cookies ranging from 10.6-11.1 mm. Spread ratio is based on the values obtained for thickness and diameter of the cookies. The cookie spread ratio decreased with addition of pearl millet. The spread ratio of the control cookies (wheat flour) was 8.30 which decreased to $7.98(\mathrm{~K})$ and 7.81 (MRB) with replacement of pearl millet. The breaking strength values of K\&MRB cookies were 1650 and $1680 \mathrm{~g}$ respectively, which was higher than the control cookies $(1600 \mathrm{~g})$ indicating that the texture of the control cookie was softer than pearl millet. The pearl millet cookies had light and crisp texture compared to the control cookies which was less crispy. Because of their glutenfree nature, cookies from $100 \%$ millet are not often prepared as they produce cookies that are tough, hard, gritty and mealy in texture and taste. They also lack spread and top surface cracks, which is a desirable attribute of cookies [9]. However, in this study, cookies were prepared from semi refined pearl millet flour which resulted in a product that had crispy and crumby texture which was acceptable by the sensory panel members.

\section{Sensory Analysis}

Research findings from a study on the influence of flour mixes on the quality of gluten-free biscuits indicated that a mixture containing millet flakes was one among the three best mixtures selected based on sensory data [18]. This shows that millets could exert beneficial influence on the quality of biscuits. However, in a comparative study on sorghum cookies and pearl millet cookies, latter were dark, less gritty and more fragile than the former [9]. A point to be noted here is that there was a wide variation in the composition and relative proportion of ingredients of the products studied, which, in all probability, resulted in the diverse quality of the products. In the present study, control cookies had offwhite color and crisper texture. Desirable attributes such as perceptible vanilla- like aroma, baked cereal aroma and sweet taste were low in this sample that consequently reduced its overall quality (8.1). On the other hand, pearl millet cookies (K\&MRB varieties) had closely matching sensory profile (Figure 4) which differed significantly from control in key attributes such as color, vanilla-like aroma, baked cereal aroma and sweet taste. Higher perceived intensities of these desirable sensory parameters significantly and positively impacted the overall quality of pearl millet cookies rated at 10.7 for $\mathrm{K}$ and 9.2 for MRB respectively as compared to control (8.1). These finding indicated that the pearl millet cookies acceptable as indicated by their higher overall quality score compared to control. Sensory panellists opined that pearl millet cookies had a combination of desirable and lasting vanilla-like aroma coupled with typical baked millet aroma. In addition, crisp and crumby texture was perceived in these cookies which further enhanced their sensory appeal making them highly palatable.

High acceptability for pearl millet cooking in a similar study was reported [1] where depigmentation of pearl millet was carried out. Results showed that native or pigmented pearl millet cookies were rated slightly less for the stated sensory attributes compared to depigmented variety of cookies. However, in the present study, it was found that dark color of the pearl millet cookies did not adversely affect the acceptability of the samples. Instead, it provided an interesting visual appeal.

\section{Conclusion}

Pearl millet flour as a replacement for refined wheat flour in the preparation of cookies was effective in enhancing its nutritional and sensory attributes. Nutritive value of the cookies improved in terms of protein, ash and mineral content (iron, calcium and phosphorus) after replacing refined wheat flour with semi refined flour of pearl millet. Out of the two varieties used, cookies from MRB had highest calcium content. The absence of gluten in pearl millet did not negatively affect the physical properties of the cookie which was similar to that of the control. QDA revealed that cookies from pearl millet were found to have higher overall quality compared to control. They had a combination of desirable and lasting vanilla-like aroma coupled with typical baked millet aroma. In addition, crisp and crumby texture perceived in these cookies further enhanced their sensory appeal making them highly palatable. This study has shown that pearl millet has a good potential for use in cookie formulation with the objective to enhance its nutritional quality and sensory properties. Further studies on effect of storage on sensory attributes and chemical composition as affected by various packaging materials are in progress.

\section{Acknowledgment}

The first author expresses her sincere thanks to CSIR - New Delhi for the award of Senior Research Fellowship. 
PROFILE OF COOKIES

Name:

- Taste the given samples and indicate intensity of perceived attributes by marking on appropriate place.

- Cleanse your palate with water in between samples.

\section{COLOUR \& APPEARANCE}

\section{Brown}

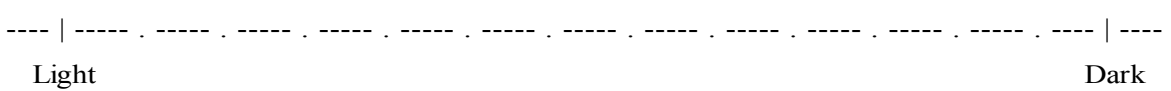

\section{TEXTURE}

Crisp

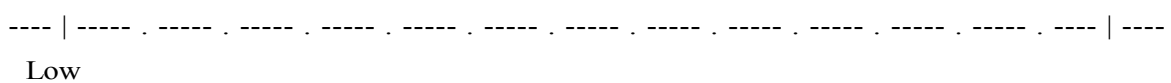

Low

Crumbly

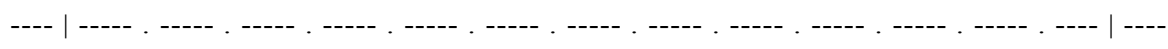

Low

High

\section{MOUTHFEEL}

Dry

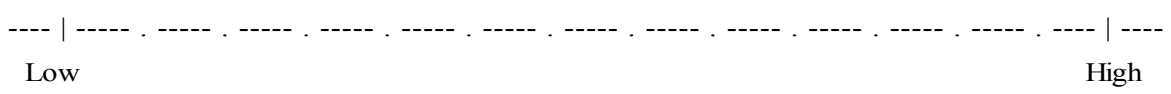

Powdery

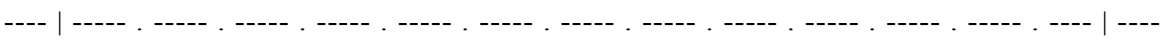

Low

\section{AROMA}

\section{Vanilla}

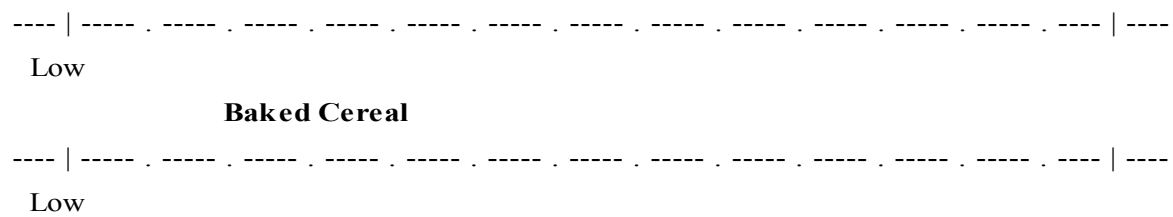

Low

High

Stale

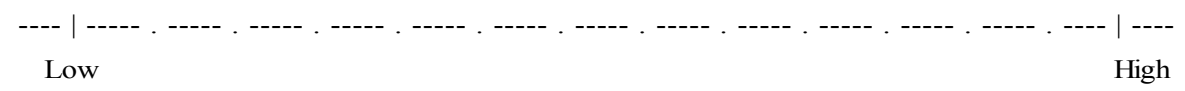

\section{Rancid}

---- | ----- . ----- . ----- . ----- . ----- . ----- . ----- . ----- . ----- . ----- . ----- . ----- . ---- | ----

Low

\section{TASTE}

Sweet

---- | ----- . ----- . ----- . ----- . ----- . ----- . ----- . ----- . ----- . ----- . ----- . ----- . ---- | ----

Low $\quad$ High

Any other

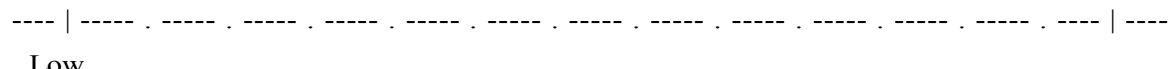

Low

High

OVERALL QUALITY

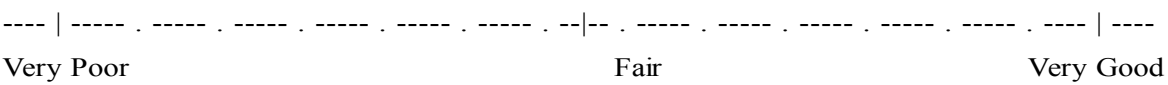

Comments:

Figure 2: Profile sheet of Quantitative Descriptive Analysis of the Cookies 
Citation: Florence Suma P, Urooj A, Asha MR, Rajiv J (2014) Sensory, Physical and Nutritional Qualities of Cookies Prepared from Pearl Millet (Pennisetum Typhoideum). J Food Process Technol 5: 377. doi:10.4172/2157-7110.1000377

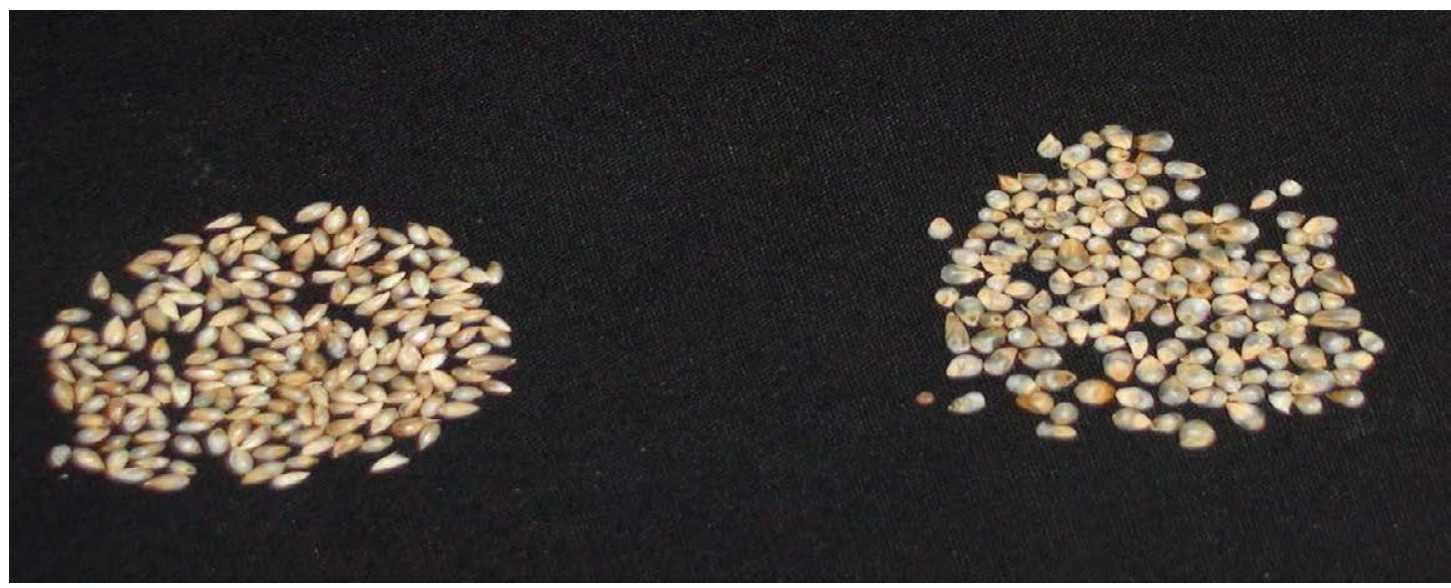

$\mathbf{K}$

MRB

K - Kalukombu

MRB - Maharashtra Rabi Bajra

Figure 3: Pictures of the Two Pearl Millet Varieties

\begin{tabular}{|c|c|c|c|}
\hline Ingredients & C & $\mathbf{K}$ & MRB \\
\hline SRFPM (g) & & $100(49.6)$ & $100(49.6)$ \\
\hline Refined Wheat Flour (g) & $100(49.6)$ & - & - \\
\hline Fat (g) & $50(24.7)$ & $50(24.7)$ & $50(24.7)$ \\
\hline Sugar (g) & $50(24.7)$ & $50(24.7)$ & $50(24.7)$ \\
\hline Vanilla Powder (g) & $2(1)$ & $2(1)$ & $2(1)$ \\
\hline Total & $202(100)$ & $202(100)$ & $202(100)$ \\
\hline
\end{tabular}

K-Kalukombu

MRB - Maharashtra Rabi Bajra

Values in the parenthesis is the percentage of ingredients

Table 2: Ingredients used in the preparation of Cookies (\%)

\begin{tabular}{|l|c|c|c|c|c|}
\hline Cookies & Moisture & Fat & Proteins & Ash & Cho* \\
\hline C & $2.57^{\mathrm{b}} \pm 0.14$ & $16.95^{\mathrm{a}} \pm 1.21$ & $6.80^{\mathrm{a}} \pm 0.22$ & $0.38^{\mathrm{a}} \pm 0.02$ & 73.3 \\
\hline K & $0.58^{\mathrm{a}} \pm 0.03$ & $19.71^{\mathrm{a}} \pm 1.09$ & $8.63^{\mathrm{b}} \pm 0.23$ & $0.93^{\mathrm{c}} \pm 0.05$ & 70.15 \\
\hline MRB & $0.34^{\mathrm{a}} \pm 0.03$ & $17.82^{\mathrm{a}} \pm 0.22$ & $8.50^{\mathrm{b}} \pm 0.33$ & $0.77^{\mathrm{b}} \pm 0.02$ & 492 \\
\hline
\end{tabular}

K-Kalukombu

MRB - Maharashtra Rabi Bajra

Means sharing the different superscripts are significantly different from each other (Tukey's - B significant difference test, $\mathrm{p} \leq 0.05$ )

Table 3: Proximate Composition of Pearl Millet Cookies $(\mathrm{g} / 100 \mathrm{~g})$

\begin{tabular}{|l|c|c|c|}
\hline Cookies & Iron & Calcium & Phosphorus \\
\hline $\mathbf{C}$ & $2.48^{\mathrm{a}} \pm 0.34$ & $18.26^{\mathrm{a}} \pm 0.16$ & $86.7^{\mathrm{a}} \pm 5.4$ \\
\hline K & $6.39^{\mathrm{b}} \pm 0.01$ & $25.70^{\mathrm{b}} \pm 0.54$ & $208.1^{\mathrm{b}} \pm 10.2$ \\
\hline MRB & $6.71^{\mathrm{b}} \pm 0.10$ & $29.36^{\mathrm{c}} \pm 0.54$ & $190.0^{\mathrm{b}} \pm 6.2$ \\
\hline
\end{tabular}

K - Kalukombu

MRB - Maharashtra Rabi Bajra

Means with different superscripts are significantly different from each other (Tukey's - B significant difference test, $p \leq 0.05$ ) Table 4: Mineral content of pearl millet cookies $(\mathrm{mg} / 100 \mathrm{~g})$

\begin{tabular}{|l|c|c|c|c|}
\hline Parameters & C & K & MRB & SEM $\mathbf{~}$ \\
\hline Diameter $(\mathbf{m m})$ & $88.0^{\mathrm{b}}$ & $87.0^{\mathrm{a}}$ & $86.7^{\mathrm{a}}$ & 86.7 \\
\hline Thickness $(\mathbf{m m})$ & $10.6^{\mathrm{a}}$ & $10.9^{\mathrm{a}}$ & $11.1^{\mathrm{a}}$ & 0.20 \\
\hline Spread ratio (D/T) & $8.30^{\mathrm{b}}$ & $7.98^{\mathrm{a}}$ & $7.81^{\mathrm{a}}$ & 0.10 \\
\hline Spread factor & $83.0^{\mathrm{b}}$ & $79.8^{\mathrm{a}}$ & $78.1^{\mathrm{a}}$ & 0.50 \\
\hline Breaking strength (g) & $1600^{\mathrm{a}}$ & $1650^{\mathrm{b}}$ & $1680^{\mathrm{b}}$ & 10 \\
\hline
\end{tabular}

K - Kalukombu

MRB - Maharashtra Rabi Bajra

SEM-Standard error of means at 15 degrees of freedom, mean in the same row followed by different superscripts differ significantly $(p \leq 0.05)$.

Table 5: Physical Characteristics of Pearl Millet Cookies

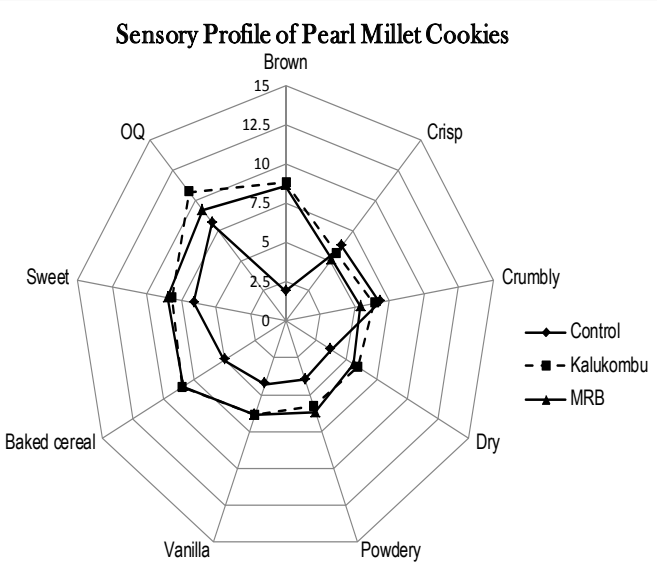

K-Kalukombu

MRB - Maharashtra Rabi Bajra

$\mathrm{OQ}$ - overall quality

Figure 4: Sensory Profile of Control and Pearl Millet Cookies 
Citation: Florence Suma P, Urooj A, Asha MR, Rajiv J (2014) Sensory, Physical and Nutritional Qualities of Cookies Prepared from Pearl Millet (Pennisetum Typhoideum). J Food Process Technol 5: 377. doi:10.4172/2157-7110.1000377

\section{References}

1. Archana R, Asna K, Salil S, Byron H (2004) Influence of depigmentation of pearl millet (Pennisetum gluacum L) on sensory attributes, nutrient composition and in vitro digestion of biscuits. LWT 37: 184-192.

2. Ali AY, Anwaar A, Asif A, Tabassum H, Muhammad AR, et al. (2012) Nutritional and functional evaluation of wheat flour cookies, supplemented with gram flour. Intr J Food Sci Nutr 64:63-68.

3. Amarender RA, Yadav OP, Dharm PM, Singh IP, Ardeshna NJ, et al. (2013) Utilization Pattern, Demand and Supply of Pearl Millet Grain and Fodder in Western India.

4. Fasasi OS (2009) Proximate, antinutritional factors and functional properties of processed pearl millet (Pennisetum glaucum). J Food Tech 7: 92-97.

5. Anu SS, Kwatra A (2006) Nutritional evaluation of pearl millet based sponge cake. J Food Sci Tech 43: 312-313.

6. Malik M, Singh U, Dahiya S (2002) Nutrient composition of pearl millet as influenced by genotypes and cooking methods. J Food Sci Tech 39: 463-468.

7. Obilana AB (2004) Encyclopedia of Grain Science: Sorghum - Production, ICRISAT, Ed- Colin Wrigley, Harold Corks, Charles E Walker, Elsevier Ltd.

8. Olatungi O, Akinrele IA, Erwards CC, Loleoso OA (1982) Sorghum and millets processing and uses in Nigeria. Cereal Foods World 27: 277.

9. Badi SM, Hoseney (1975) Use of sorghum and pearl millet flours in Cookies. Cereal Chem 53: 733-738.
10. Florence SP, Asna U (2011) Nutrients, antinutrients \& bioaccessible mineral content (invitro) of pearl millet as influenced by milling. J Food Sci Technol 51: 756-761.

11. AOAC (2005) Official Methods of Analysis, (18thedn). Association of Official Analytical Chemists, Washington DC.

12. Raghuramulu N, Nair M, Kalyansundaram S (1983) A manual for laboratory techniques, National Institute of Nutrition, Indian Council for Medical Research, Jami-Osmania, Hyderabad, India.

13. Taussky HH, Shorr E (1953) A micro colorimetric method for determination of inorganic phosphorus. J Bio Chem 202: 675-685.

14. Anon (2010) All India coordinated pearl millet improvement project annual report 2009-2010.

15. Chevallier S, Colonna P, Lourdin D, Valle DG (2000) Contribution of major ingredients during baking of biscuit dough systems. J Cereal Sci 31: 241-252.

16. Jain RK, Satish B (1997) Production of Low-fat Grits from Pearl Millet. J Food Eng 31: 297-304.

17. Bram P, Edith W, Hans G, Kristof B, Jan AD (2008) The role of gluten in a sugar-snap cookie system: A model approach based on gluten-starch blends. J Cereal Sci 48: 863-869.

18. Tilman JS, Colm M O’B, Denise Mc C, Anja D, Elke KA (2003) Influence of gluten-free flour mixes and fat powders on the quality of gluten-free biscuits. Eur J Food Res Tech 216: 369-376. 